\title{
Analisis Transportasi Pengangkutan Sampah di Kota Medan Menggunakan Dynamic Programming
}

\author{
Kana Saputra $\mathbf{S}^{1}$, Nur Hairiyah Harahap ${ }^{2}$, Jufita Sari Sitorus ${ }^{3}$ \\ 1,2,3Program Studi IImu Komputer, Universitas Negeri Medan \\ e-mail: ${ }^{1}$ kanasaputras@unimed.ac.id, ${ }^{2}$ nurhairiyahharahap0400@gmail.com \\ 3jufitas21@gmail.com
}

\begin{abstract}
Abstrak
Permasalahan sampah perkotaan di Indonesia merupakan masalah yang belum terselesaikan secara tuntas, terutama di Kota Medan. Salah satu penyumbang sampah terbesar di Kota Medan adalah pasar tradisional. Permasalahan sampah di Kota Medan adalah pengelolaan sampah yang berhubungan dengan pengendalian timbunan sampah. Permasalahan ini dapat diatasi dengan cara mengatur proses pemindahan dan pengangkutan sampah berdasarkan rute yang optimal. Tujuan dari penelitian ini adalah untuk menganalisis sistem transportasi pengangkutan sampah di beberapa pasar tradisional yang ada di Kota Medan dan membandingkan kebutuhan biaya transportasi di setiap pola pengumpulan sampah. Tahapan yang dilakukan adalah mengumpulkan data jarak pool ke setiap pasar tradisonal, jarak antar pasar tradisional, dan jarak setiap pasar tradisional ke TPA, penerapan Algoritma Dynamic Programming untuk menentukan jarak terpendek, dan menghitung biaya opersional yang dibutuhkan. Kendaraan yang digunakan adalah Armroll Truck Container. Sampel data yang digunakan adalah 6 pasar tradisional yang berada di Kota Medan. Hasil penelitian menunjukkan bahwa algoritma Dynamic Programming dapat menentukan rute yang optimal untuk 6 pasar tradisional yang ada di Kota Medan dengan jumlah Armroll Truck Container sebanyak 2 dan perhitungan kebutuhan biaya BBM perhari sebesar Rp. 672.002,--
\end{abstract}

Kata kunci: Dynamic Programming, Kota Medan, Pasar Tradisional, Sampah Perkotaan

\begin{abstract}
Abstrack
The problem of urban waste in Indonesia is a problem that has not been completely resolved, especially in Medan. One of the biggest contributors of waste in the city of Medan is the traditional market. The problem of urban waste in the Medan is waste management that is related to the control of waste pile. This problem can be overcome by regulating the process of moving and transporting waste according to the optimal route. The aim of this research is to analyze the transportation system of waste transportation in several traditional markets in the Medan and to compare the needs of transportation costs in each waste collection pattern. The steps taken are collecting distance pool data to each traditional market, distance between traditional markets, and distance of each traditional market to landfill, applying Dynamic Programming Algorithm to determine the shortest distance, and calculating the required operational costs. The vehicle used is the Armroll Truck Container. The data used was 6 traditional markets in the Medan. The results showed that the Dynamic Programming algorithm can determine the optimal route for 6 traditional markets in the Medan with a total of 2 Armroll Truck Container and the calculation of the needed fuel oil cost per day is Rp. 672,002.
\end{abstract}

Keywords: Dynamic Programming, Medan, Traditional Market, Urban Waste

\section{Pendahuluan}

Sampah perkotaan di Indonesia merupakan masalah besar yang masih menjadi tantangan bagi Pemerintah Kota. Permasalahan ini dapat dilihat dari total sampah yang dihasilkan oleh masyarakat dengan perkiraan hanya $60 \%$ sampah yang terangkut ke Tempat Pembuangan Akhir (TPA) oleh Dinas Kebersihan Kota, sebagian besar sampah yang tidak terangkut biasanya dibakar atau dibuang ke sungai (Damanhuri \& Padmi, 2010). Pembakaran sampah atau pembuangan sampah ke sungai dapat mengakibatkan kerusakan lingkungan, yaitu pencemaran udara dan air.

Pengelolaan sampah yang baik merupakan proses yang dibutuhkan oleh 
Pemerintah Kota. Pengelolaan sampah adalah pengaturan yang berhubungan dengan pengendalian timbulan sampah, penyimpanan, pengumpulan, pemindahan dan pengangkutan, pengolahan dan pembuangan sampah (Effendy \& Lubis, 2018). Salah satu cara yang dapat dilakukan oleh Pemerintah Kota adalah mengatur dan mengoptimalkan kegiatan pemindahan sampah. Pemindahan sampah adalah kegiatan memindahkan sampah hasil pengumpulan ke dalam alat pengangkutan untuk dibawa ke tempat pembuangan akhir (Fatoni, Imanuddin L, \& Darmawan, 2017). Penentuan rute pemindahan sampah akan berpengaruh terhadap biaya operasional truck yang digunakan, seperti Bahan Bakar Minyak (BBM) yang digunakan. Penelitian ini akan mencari rute yang optimal pemindahan sampah dari pasar tradisonal ke TPA.

Penentuan rute optimal untuk pengangkutan sampah pernah dilakukan di Kota Makasar menggunakan Algoritma Greedy (Akhsa, Zainuddin, \& Achmad, 2019), di Kota Bandung menggunakan menggunakan Vehicle Routing Problem (Setiady, Jati, \& Azmi, 2016), dan di Kota Marauke menggunakan Algoritma Dijkstra (Andayani \& Perwitasari, 2014). Penelitian yang telah dilakukan menunjukkan bahwa pengangkutan sampah merupakan permasalahan yang spesifik untuk masingmasing Kota dan belum menerapkan Algoritma Dynamic Programming.

Penerapan Algoritma Dynamic Programing merupakan solusi untuk mencari jarak terpendek atau tercepat, dari dua titik awal dan akhir, yang melalui banyak titik antara dengan berbagai kemungkinan jalur (Susdarwono, 2020). Algoritma Dynamic Programming pernah diimplementasikan untuk permasalahan knapsack pada transportasi kargo dengan hasil yang optimal dibadingkan dengan Algoritma Greedy (Sampurno, Sugiharti, \& Alamsyah, 2018). Dari penelitian tersebut menunjukkan bahwa Algoritma Dynamic Programming optimal untuk permasalahan tertentu. Penelitian ini akan menggunakan Algoritma Dynamic Programming untuk menentukan rute optimal dalam pengangkutan sampah di Kota Medan.

\section{Metode Penelitian}

Tahapan pada penelitian ini adalah sebagai berikut:

\section{Pengumpulan Data}

Data yang dikumpulkan adalah data jarak (menggunakan Google Maps) pada setiap simpul pasar tradisional (sebagai TPS) menuju ke TPA, harga BBM terbaru, dan banyaknya ritasi perharinya. Penelitian ini tidak mempertimbangkan volume sampah pada setiap pasar tradisional (TPS) dan kendaraan hanya 1 kali sehari mengangkut sampah di pasar tradisional (TPS) sesuai dengan Kajian Pengelolaan Sampah dan SDM Kebersihan di Kota Medan (Pemerintah Kota Medan, 2013). Pola pengangkutan yang digunakan adalah pola komunal langsung, dimana kegiatan pengambilan sampah dari masing-masing titik komunal dan diangkut ke lokasi pembuangan akhir (Badan Standarisasi Nasional, 2002). Pool berada di Dinas Kebersihan dan Pertamanan Kota Medan yang beralamat di Jalan Pinang Baris No. 144, Lalang, Kecamatan Medan Sunggal.

\section{Pengolahan Data}

Data yang telah dikumpulkan disusun sesuai dengan jarak masing-masing simpul, kemudian dihitung total kebutuhan biaya. Kendaraan yang digunakan untuk mengangkut sampah dari pasar tradisional ke TPA menggunakan truck jenis Armroll Truck Container (Pemerintah Kota Medan, 2013).

\section{Implementasi Algoritma Dynamic Programming}

Algoritma Dynamic Programming digunakan untuk menyelesaikan berbagai masalah, salah satunya adalah permasalahan mengenai penentuan jarak minimum antar simpul. Dynamic Programming dapat dikatakan pula sebagai metode pemecahan masalah dengan cara menguraikan solusi menjadi sekumpulan langkah (step) atau tahapan (stage) sedemikian rupa sehingga solusi dari persoalan dapat dipandang dari serangkaian keputusan yang saling berkaitan (Aristi, 2014).

Langkah-langkah Algoritma Dynamic Programming adalah sebagai berikut (Prasetiyowati \& Wlcaksana, 2013):

a. Membagi masalah menjadi submasalah yang lebih kecil dan tidak independen.

b. Menyelesaikan submasalah secara rekursif.

c. Menggabungkan solusi untuk memecahkan masalah asli. 


\section{Hasil dan Pembahasan}

Pada umumnya pengumpulan sampah dilakukan pada pagi atau siang hari, tetapi untuk tempat-tempat tertentu seperti pasar biasanya pengumpulan sampah dilakukan pada malam hari. Ritasi pengangkutan sampah kegiatan komersial selain pasar tradisional adalah 2 kali sehari dan pasar tradisional 1 kali sehari.

Proses kegiatan pengumpulan dan pengangkutan sampah pasar yang ada di Kota Medan menggunakan sistem pengumpulan komunal langsung. Kendaraan yang digunakan adalah kendaraan jenis Armroll Truck Container karena cocok untuk lokasi pasar yang jumlah timbunan sampahnya banyak. Penelitian ini membandingkan total jarak tempuh untuk 2 kendaraan, 3 kendaraan, dan 6 kendaraan dengan jumlah sampel Depo (Pasar Tradisional) berjumlah 6 yang berada di Kota Medan.

Total jarak tempuh 1 kendaraan untuk mengangkut sampah setiap rute pengangkutan adalah dengan menjumlahkan panjang setiap rute (dari Pool - Depo - TPA - Pool). Perhitungan total jarak tempuh perhari untuk 6 kendaraan dapat dilihat pada Tabel 1.

Tabel 1. Total Jarak Tempuh Perhari dengan 6 Kendaraan

\begin{tabular}{|c|l|c|}
\hline Kendaraan & \multicolumn{1}{|c|}{$\begin{array}{c}\text { Nama } \\
\text { Depo/TPS }\end{array}$} & $\begin{array}{c}\text { Total Jarak } \\
(\mathrm{km})\end{array}$ \\
\hline 1 & Pusat Pasar & 50,4 \\
\hline 2 & $\begin{array}{l}\text { Pasar } \\
\text { Sukaramai }\end{array}$ & 54,9 \\
\hline 3 & $\begin{array}{l}\text { Pasar Kampung } \\
\text { Lalang }\end{array}$ & 43 \\
\hline 4 & $\begin{array}{l}\text { Pasar Sei } \\
\text { Sikambing }\end{array}$ & 43,6 \\
\hline 5 & $\begin{array}{l}\text { Pasar Simpang } \\
\text { Limun }\end{array}$ & 58,5 \\
\hline 6 & Pasar Petisah & 47,1 \\
\hline & Total & $\mathbf{2 9 7 , 5}$ \\
\hline
\end{tabular}

Untuk penggunaan kendaraan angkut sampah yang beroperasi sebanyak 2 kendaraan maka rute dan pola pengumpulan sampah berubah dan berpengaruh terhadap total jarak tempuh. Penentuan Depo yang dilalui oleh kendaraan berdasarkan pada jarak terdekat dengan TPA setelah proses pembuangan sampah dari Depo sebelumnya selesai dilakukan.
Untuk penggunaan kendaraan angkut sampah yang beroperasi sebanyak 3 kendaraan maka rute dan pola pengumpulan sampah juga berubah. Total jarak tempuh kendaraan pengangkutan sampah menggunakan 3 kendaraan dapat dilihat pada Tabel 2.

Tabel 2. Total Jarak Tempuh Perhari dengan 3 Kendaraan

\begin{tabular}{|c|c|c|}
\hline Kendaraan & Rute & $\begin{array}{c}\text { Total Jarak } \\
(\mathrm{km})\end{array}$ \\
\hline 1 & $\begin{array}{c}\text { Pool - Pasar } \\
\text { Kampung } \\
\text { Lalang - TPA - } \\
\text { Pusat Pasar - } \\
\text { TPA - Pool }\end{array}$ & 79,2 \\
\hline \multirow{2}{*}{2} & $\begin{array}{c}\text { Pool - Pasar } \\
\text { Sei Kambing - } \\
\text { TPA - Pasar } \\
\text { Sukaramai - } \\
\text { TPA - Pool }\end{array}$ & 85,7 \\
\hline 3 & $\begin{array}{c}\text { Pool - Pasar } \\
\text { Petisah - TPA - } \\
\text { Pasar Simpang } \\
\text { Limun - TPA - } \\
\text { Pool }\end{array}$ & $\mathbf{9 4 , 3}$ \\
\hline \multicolumn{2}{|c|}{ Total } & $\mathbf{2 5 9 , 2}$ \\
\hline
\end{tabular}

Total jarak tempuh kendaraan pengangkutan sampah menggunakan 2 kendaraan dapat dilihat pada Tabel 3.

Tabel 3. Total Jarak Tempuh Perhari dengan 2 Kendaraan

\begin{tabular}{|c|c|c|}
\hline Kendaraan & Rute & $\begin{array}{c}\text { Total Jarak } \\
(\mathrm{km})\end{array}$ \\
\hline 1 & $\begin{array}{c}\text { Pool - Pasar } \\
\text { Kampung Lalang } \\
\text { - TPA - Pasar } \\
\text { Petisah - TPA - } \\
\text { Pasar } \\
\text { Sukaramai - } \\
\text { TPA - Pool }\end{array}$ & 119,2 \\
\hline 2 & $\begin{array}{l}\text { Pool - Pasar Sei } \\
\text { Kambing - TPA } \\
\text { - Pusat Pasar - } \\
\text { TPA - Pasar } \\
\text { Simpang Limun } \\
\text { - TPA - Pool }\end{array}$ & 127 \\
\hline \multicolumn{2}{|r|}{ Total } & 246,2 \\
\hline
\end{tabular}

Hasil perhitungan dari ketiga tabel tersebut menunjukkan bahwa total jarak tempuh perhari dengan 2 kendaraan lebih optimal dibandingkan dengan pola pengangkutan dan jumlah kendaraan yang lain, yaitu 246,2 km. 
Data pada Tabel 1, 2, dan 3 dapat digunakan untuk menghitung kebutuhan bahan bakar perhari dan biaya yang diperlukan. Kendaraan angkut sampah jenis Armroll Truck Container ini menggunakan bahan bakar berupa solar bersubsidi dengan harga perliternya senilai Rp. 5.150,- (per januari 2020). Jarak tempuh untuk perliternya adalah sejauh $1,89 \mathrm{~km}$ atau kebutuhan bahan bakar untuk menempuh $1 \mathrm{~km}$ adalah 0,53 liter (Yunita \& Ali, 2014).

Kebutuhan biaya yang dibutuhkan perhari untuk setiap pola yang digunakan adalah dengan cara mengalikan jarak tempuh total perhari dengan bensin per-km nya dan harga bahan bakar perliternya.

Kebutuhan biaya $=$ total jarak tempuh/hari $\times 0,53$ liter $/ \mathrm{km} \times$ Rp. 5.150,-/liter

Dari hasil perhitungan dapat diketahui total biaya kebutuhan untuk setiap rute perharinya adalah sebagai berikut.

Tabel 4. Total Kebutuhan Biaya BBM Perhari

\begin{tabular}{|c|c|c|}
\hline $\begin{array}{c}\text { Jumlah } \\
\text { Kendaraan }\end{array}$ & $\begin{array}{c}\text { Total } \\
\text { BBM } \\
\text { (Liter) }\end{array}$ & $\begin{array}{c}\text { Total Biaya } \\
\text { Perhari } \\
(\mathrm{Rp})\end{array}$ \\
\hline 6 & 157,675 & $812.026,-$ \\
\hline 3 & 137,376 & $707.486,-$ \\
\hline 2 & 130,486 & $672.002,-$ \\
\hline
\end{tabular}

Berdasarkan perhitungan total kebutuhan biaya BBM perhari menunjukkan bahwa dengan 2 kendaraan lebih murah dibandingkan dengan pola dan jumlah kendaraan lainnya, yaitu Rp. 672.002,-.

\section{Kesimpulan}

Adapun kesimpulan yang diperoleh dari hasil dan pembahasan adalah sebagai berikut:

1. Algoritma Dynamic Programming optimal untuk menentukan rute tercepat dengan sampel 6 pasar tradisional yang ada di Kota Medan menggunakan 2 Armroll Truck Container.

2. Total biaya BBM perhari yang dibutuhkan untuk pola pengumpulan komunal langsung dengan 2 kendaraan lebih murah dibandingkan pola dan jumlah kendaraan lainnya, yaitu sebesar Rp. 672.002,-.

\section{Referensi}

Akhsa, A. T. P. D., Zainuddin, Z., \& Achmad, A. (2019). Optimasi Rute Menggunakan Algoritma Greedy Pada Pengangkutan Sampah di Kota Makassar, 10(1), 1-10.

Andayani, S., \& Perwitasari, E. W. (2014). Penentuan Rute Terpendek Pengambilan Sampah di Kota Merauke Menggunakan Algoritma Dijkstra. In Seminar Nasional Teknologi Informasi \& Komunikasi Terapan (pp. 164-170).

Aristi, G. (2014). Perbandingan Algoritma Greedy, Algoritma Cheapest Insertion Heuristic dan Dynamic Programming Dalam Penyelesaian Travelling Salesman Problem. Jurnal Paradigma, 16(2), 52-58.

Badan Standarisasi Nasional. (2002). Tata Cara Teknik Operasional Pengelolaan Sampah Perkotaan.

Damanhuri, E., \& Padmi, T. (2010). Pengelolaan Sampah.

Effendy, I., \& Lubis, I. P. L. (2018). Manajemen Tata Kelola Sampah Di Perkotaan ( Studi Kasus Di Kota Medan ). Jurnal Ready Star, 152-160.

Fatoni, N., Imanuddin L, R., \& Darmawan, A. R. (2017). Pendayagunaan Sampah Menjadi Produk Kerajinan. Jurnal Pemikiran Agama Untuk Pmeberdayaan, 17, 83-96.

Pemerintah Kota Medan. (2013). Kajian Model Pengelolaan Sampah.

Prasetiyowati, M. I., \& Wlcaksana, A. (2013). Implementasi Algoritma Dynamic Programming untuk Multiple Constraints Knapsack Problem. In Seminar Nasional Aplikasi Teknologi Informasi (SNATI) (pp. 6-13).

Sampurno, G. I., Sugiharti, E., \& Alamsyah. (2018). Comparison of Dynamic Programming Algorithm and Greedy Algorithm on Integer Knapsack Problem in Freight Transportation. Scientific Journal of Informatics, 5(1), 40-49.

Setiady, R. R. D., Jati, A. N., \& Azmi, F. (2016). Perancangan dan Implementasi Metode Heuristic Untuk Vehicle ROuting Problem Pada Pengangkutan Sampah, 3(1), 802809.

Susdarwono, E. T. (2020). Pemrograman Dinamik: Analisa Jaringan Menggunakan Prosedur PERT dan AHP Dalam Penyelesaian 
JURNAL INFORMATIKA, Vol.7 No.2 September 2020

ISSN: 2355-6579 | E-ISSN: 2528-2247

Permasalahan Ekonomi Pertahanan. Jurnal El-Hamra (Kependidikan Dan Kemasyarakatan), 5(1), 1-9.

Yunita, A. T., \& Ali, M. (2014). Analisis Sistem Transpoertasi Sampah Kota Tuban Menggunakan Dynamic Programming. Jurnal IImiah Teknik Lingkungan, 6(1), 45-52. 